\title{
The Effect of Corporation Culture on the Staff's Commitment in CMC Telecom Vietnam
}

\author{
Ha Nam Khanh Giao \\ Faculty of Air Transport Facilities, Vietnam Aviation Academy, Ho Chi Minh City, Vietnam
}

\section{Email address:}

khanhgiaohn@yahoo.com

\section{To cite this article:}

Ha Nam Khanh Giao. The Effect of Corporation Culture on the Staff's Commitment in CMC Telecom Vietnam. Science Journal of Business and Management. Vol. 7, No. 1, 2019, pp. 23-32. doi: 10.11648/j.sjbm.20190701.14

Received: January 31, 2019; Accepted: March 19, 2019; Published: April 29, 2019

\begin{abstract}
The research aims at investigating how the factors of corporation culture affect on the staff's commitment at CMC Telecom Vietnam, by intervewing 199 staff. The method of convenience sampling, Cronbach's Alpha analysis, EFA analysis and multiple regression analysis were used with the SPSS program. The result shows that the affects of the factors of corporation culture on the staff's commitment at CMC Telecom Vietnam decreasingly: Innovativeness, Teamwork, Training and Development, Reward and Record, Organization Communication. The research also suggests some managerial recommendations to the corporate management to enhance the commitment of the staff.
\end{abstract}

Keywords: Organization Culture, Staff's Commitment, CMC Telecom Vietnam

\section{Introduction}

Over the past few decades, organization culture has been an important topic in business management research because it affects organizational and personal aspects such as commitment, loyalty and satisfaction of employees at work. Organization culture is considered a management philosophy, the way organizations manage to improve the performance of their work as well as the ability to influence the thoughts, emotions and organization communication.

After a period of development, in order to timely adapt to changes in the business environment, CMC Telecom Corporation has been conducting a comprehensive restructuring. The process of organizational re-structuring, the change of the working apparatus, the way of working, organization culture, has led to significant changes in personnel. In 2015 and 2016, the retirement rate of 15.44\%, and the recruitment of a large number of staff made it costly, time consuming for $\mathrm{CMC}$ Telecom to train and recruit. The study of organization culture at CMC Telecom which is conducted in order to determine the impact on the staff commitment is very necessary.

\section{Theoretical Basis}

\subsection{Concept of Organization Culture}

There are different definitions of culture, each defining a different way of seeing and evaluating. According to UNESCO: "Culture is that complex whole which includes knowledge, beliefs, arts, morals, laws, customs, and any other capabilities and habits acquired by a human as a member of society

Some definitions of organization culture: organization culture is symbols, languages, ideologies, rituals, and myths [27]; organization culture is a product, a history, a thing based on symbols, abstractions from behavior and products of behavior [14]. Culture is a pattern of fundamental ideas invented, discovered, or developed by a certain group of people when they learn how to deal with the likes. Confident with the outside and integrated with the inside - Operates well enough to be considered effective and therefore is used to teach new employees how to cognize, think, and feel when dealing with these problems properly [32].

Culture organization is the key to a superior business and the function of leadership is to create and manage culture. Experienced leaders and researchers in the area of corporate strategy and development have suggested that the examination of cultural issues at the enterprise level is absolutely necessary [32].

Organization Culture Scale 
Organization culture has attracted the attention of human resource managers, especially in the past three decades. There has been a great deal of research done on this area and also many organization culture models are presented (Table 1), some are verified to have a significant impact on employee behavior and attitude in many Asian countries [15].

Table 1. Synthesis of organization culture components.

\begin{tabular}{|ll}
\hline Authors & Organization culture components \\
\hline$[34]$ & Innovation culture \\
& Supporting culture \\
& Administration culture \\
& Innovation and risk acceptance \\
& Interested in details \\
& Orientation of effectiveness / results \\
& Orientation of cooperation and teamwork \\
& Conflict and competition \\
\hline$[26]$ & Support \\
& Emphasis of development and reward \\
& Resolution \\
& Power \\
& Role \\
& Task \\
& Support \\
& Delegation \\
& Consistency \\
\hline Ad] & Adaptability \\
& Mission \\
\hline [6] & Organization communication \\
& Training and development \\
& Rewards and records \\
& Making a decision \\
& Accepting risk by innovation and improvement \\
& Plan orientation \\
& Teamwork \\
& Management policies \\
& Salary, bonus and recognition \\
\hline 50$]$ & \\
\hline
\end{tabular}

\begin{tabular}{ll}
\hline Authors & Organization culture components \\
\hline & Training and development \\
& Organization communication \\
& Teamwork \\
& Accreditation - support \\
& Unitedness - Team spirit \\
& Improving work efficiency \\
& Principles, rules \\
& Continuous learning \\
& Strategy \\
& Reaching goal \\
& Reliable relationships \\
& Innovation encouragement \\
& Working environment \\
& Aiming to customers \\
& Support in the way of management \\
& Competitiveness \\
& Social responsibility \\
& Support \\
& Innovation \\
& Orientation to results \\
& Stability \\
& Emphasis of reward \\
\hline [18] & \\
&
\end{tabular}

Source: Summary of the author

\subsection{The Concept of Staff Commitment}

Staff commitment is a long-term commitment to the organization, so organizations often try to push their staff's commitment higher to achieve stability and reduce costs. Employees who highly commit to sticking with a organization will work harder to achieve their goals. There have been many studies of staff commitment (Table 2).

Table 2. Summary of staff commitment.

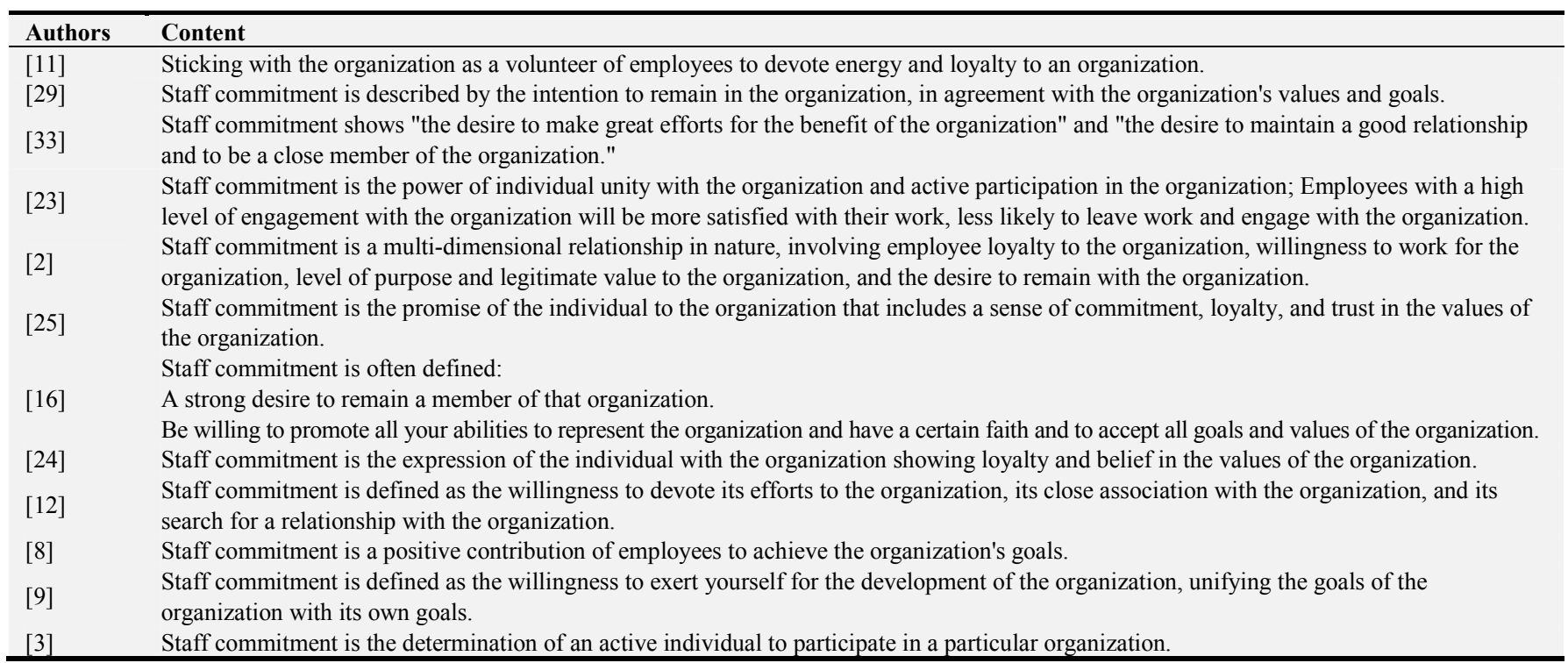

Source: Summary of the author

Thus, staff commitment is a psychological state that implies the attachment of an individual to an organization, to a profession. Individuals with a high degree of attachment to the organization will be happy with their work, with little or no 
involvement in other organizations.

\subsection{The Components of Staff Commitment}

There have been many studies on staff commitment:

Table 3. Perspectives on the scales of staff commitment.

\begin{tabular}{|c|c|}
\hline Authors & Scales \\
\hline [23] & $\begin{array}{l}\text { Identification: Individual goals align with organizational goals, have strong beliefs, and accept the goals and values of the organization. } \\
\text { Loyalty: Strongly want to maintain the membership of the organization. } \\
\text { Involvement: Be involved in the activities of the organization and always try voluntarily for the organization }\end{array}$ \\
\hline [1] & $\begin{array}{l}\text { Value commitment: Adherence to the goals of the organization. } \\
\text { Commitment to stay: Commitment to maintaining their membership in the organization. }\end{array}$ \\
\hline [25] & $\begin{array}{l}\text { Compliance: The attraction for special rewards } \\
\text { Identification: The attachment to the desire to integrate with the organization. } \\
\text { Internalisation: Charisma by the suit, the similarity between the value of the individual and the value of the organization. }\end{array}$ \\
\hline [28] & $\begin{array}{l}\text { Moral: Acceptance and agreement with the organization's goals. } \\
\text { Calculative: Consensus with the organization because staff are satisfied with incentives when making contributions to the organization. } \\
\text { Alienative: Employees stay behind because of the pressures of the environment, although they find that what they receive is no longer } \\
\text { commensurate with their efforts. }\end{array}$ \\
\hline [21] & $\begin{array}{l}\text { Affective Commitment: Emotionally attached, consensual and drawn into the organization. } \\
\text { Continuance Commitment: Sticking to the fact that employees find high costs (opportunity costs) to leave the organization. } \\
\text { Normative Commitment: Feeling obliged to continue the work. }\end{array}$ \\
\hline [19] & $\begin{array}{l}\text { Value: Confidence and acceptance of organizational goals and values and willingness to work for the organization. } \\
\text { Continuance: Desire to remain a member of the organization. }\end{array}$ \\
\hline [10] & $\begin{array}{l}\text { Affective: The degree to which an individual is psychologically attached to the organization through feelings of loyalty, love for the } \\
\text { organization, enthusiasm for the organization, satisfaction and the sense of belonging to the organization. } \\
\text { Continuance The extent to which individuals feel attached to the organization because they have to lose too much if leaving their } \\
\text { organization. } \\
\text { Moral The degree to which an individual is psychologically attached to the organization through the acquisition of the organization's goals, } \\
\text { values, and mission. }\end{array}$ \\
\hline
\end{tabular}

Source: Summary of the author

The definition of staff commitment including Affective Commitment, Continuance Commitment, Normative Commitment: [21] is the most widely accepted and used in current studies, with three types of "emotion", "compulsory" and "standard" attachment. The emotional attachment makes the dependent variable.

\subsection{The Relationship Between Organization Culture and Staff Commitment}

Many researchers have investigated the relationship between organization culture and staff commitment [4]. Firms that have organization culture in the workplace have a more engaged workforce [13]. Organization culture is the same as a premise of staff commitment [21].

Organization culture directly and indirectly influences staff commitment through values and beliefs of organizational policies [17]. This influence occurs when the organization members find the value and trust of the organization similar to the value and trust of the individual [21]. The suitability of organization culture and its staff will increase staff commitment [20-35]. The theoretical connection between organization culture and staff commitment suggests that staff commitment is the result of organization culture [17].

\subsection{Recommended Research Model}

This study conducted the model based on organization culture with four components: Organization Communication;
Rewards and Records, Training and Development, Teamwork. Qualitative research results suggest two additional organization culture: "Innovativeness" and "Empowerment" in the research model at CMC Telecom Vietnam (Figure 1).

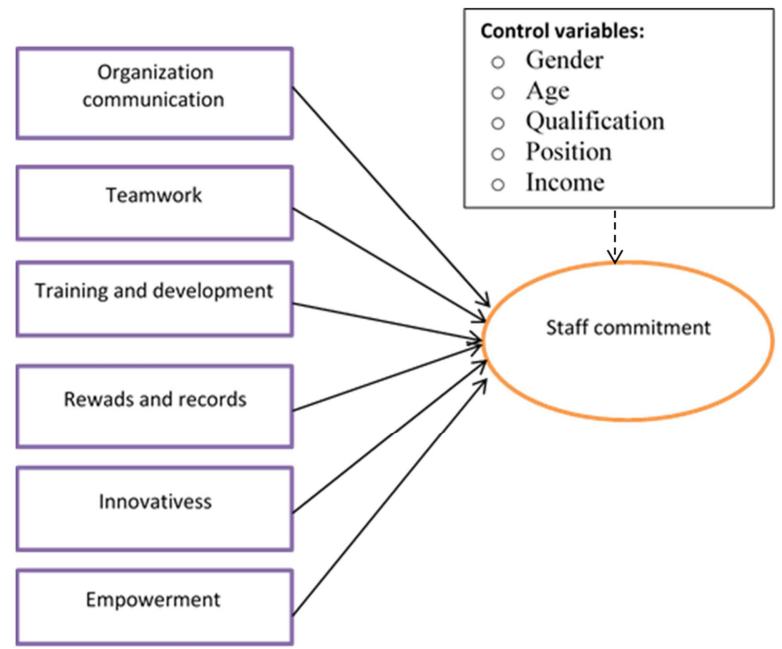

Source: Proposed by the author

Figure 1. The proposed research model.

$\mathrm{H}_{1}$ : Organization Communication affects the Staff commitment positively.

$\mathrm{H}_{2}$ : Teamwork affects the Staff commitment positively..

$\mathrm{H}_{3}$ : Training and development affect the Staff commitment positively. 
$\mathrm{H}_{4}$ : Rewards and records affects the Staff commitment positively.

$\mathrm{H}_{5}$ : Innovativeness affects the Staff commitment positively.

$\mathrm{H}_{6}$ : Empowerment affects the Staff commitment positively.

\section{Methods}

The combination of qualitative research and quantitative research was used. After reviewing the literature, the scale went through the expert opinions for revising, these experts are from CMC Telecom as well as from the Universities. Then a focus group with 8 staff was conducted. Then, a trial quetionnaires was built up and sent to 50 staff. The result from all the activities was the formal quaestionnaire. 367 questionaires were sent to the staff of CMC Telecom Vietnam, collecting 230 samples, after removing the unsatisfactory samples, the remaining is 199 sheets, achieving $86.52 \%$. These 199 is the formal sample used for quantitative research.

\section{Research Result and Discussion}

\subsection{Statistics Description}

Female survey results were $39.2 \%$, male $60.8 \%$; Age of
26-35 accounted for $47.7 \%$, from $18-25$ accounted for $31.7 \%$, 36-45 accounted for $14.6 \%$, over 45 accounted for $6.0 \%$; Postgraduate degrees accounted for $8.0 \%$ (16 persons); the univeristy was $43.2 \%$, the college was $31.2 \%$, the secondary school was $17.6 \%$ (35 people); Number of employees with monthly income of 5-10 million VND accounted for $56.3 \%$, over $10-15$ million VND was $16.6 \%$, under 5 million VND was $14.6 \%$, over 15 million was $12.6 \%$; Those who worked for 1-2 years accounted for $30.7 \%$, less than 1 year was $28.6 \%$, from $5-7$ years was $22.6 \%$, from $2-5$ years was $18.1 \%$, employees accounted for $87.4 \%$, managers accounted for $12.6 \%$.

\subsection{Measure the Reliability of the Scale by Cronbach's Alpha}

After analyzing Cronbach's alpha for the first time, the variables rejected inclued: COMMUNI 3, TEAM $_{6}$, TRAIN $_{2}$, TRAIN $_{6}, \quad$ REWARD $_{3}, \quad \mathrm{INNOV}_{3}, \quad \mathrm{INNOV}_{5}$ as item-total correlation of variables was less than 0.3 . In the results of the second test, the above scales had a high Cronbach Alpha coefficient $(>0.6)$, the item total correlation was greater than 0.3 (Table 4), so it was used for the next EFA.

Table 4. Results of Cronbach's alpha analysis and item total correlation.

\begin{tabular}{llll}
\hline Variables & No. of observed variables & Cronbach's alpha & Minimum item - total correlation \\
\hline Organization communication & 4 & 0.816 & 0.521 \\
Training and Development & 4 & 0.894 & 0.711 \\
Rewads and Records & 4 & 0.748 & 0.619 \\
Teamwork & 5 & 0.758 & 0.309 \\
Innovativess & 4 & 0.850 & 0.747 \\
Staff commitment & 5 & 0.843 & 0.843 \\
\hline
\end{tabular}

Source: Analysis result

\subsection{Exploratory Factor Analysis}

Bartlett's test in factor analysis shows that sig $=0.000$; The coefficient of KMO is 0.767 (between 0.5 and 1 ), the observed variables in the overall correlation coefficient and the explainatory factor analysis (EFA) are appropriate.

Table 5. EFA results of organization culture.

\begin{tabular}{|c|c|c|c|c|c|c|}
\hline \multirow{2}{*}{ Observed variables } & \multicolumn{6}{|c|}{ Factor loadings } \\
\hline & 1 & 2 & 3 & 4 & 5 & 6 \\
\hline $\mathrm{COMMUN}_{2}$ & .861 & & & & & \\
\hline COMMUN $_{1}$ & .771 & & & & & \\
\hline $\mathrm{COMMUN}_{4}$ & .743 & & & & & \\
\hline $\mathrm{TEAM}_{5}$ & .717 & & & & & \\
\hline $\mathrm{COMMUN}_{5}$ & .671 & & & & & \\
\hline TRAIN $_{5}$ & & .906 & & & & \\
\hline TRAIN $_{1}$ & & .846 & & & & \\
\hline TRAIN $_{3}$ & & .827 & & & & \\
\hline TRAIN $_{4}$ & & .808 & & & & \\
\hline $\mathrm{INNOV}_{2}$ & & & .904 & & & \\
\hline $\mathrm{INNOV}_{1}$ & & & .831 & & & \\
\hline $\mathrm{INNOV}_{4}$ & & & .811 & & & \\
\hline $\mathrm{INNOV}_{6}$ & & & .713 & & & \\
\hline $\mathrm{TEAM}_{4}$ & & & & .822 & & \\
\hline TEAM $_{2}$ & & & & .811 & & \\
\hline TEAM $_{1}$ & & & & .724 & & \\
\hline $\mathrm{TEAM}_{3}$ & & & & .689 & & \\
\hline REWARD $_{2}$ & & & & & .853 & \\
\hline REWARD $_{4}$ & & & & & .749 & \\
\hline
\end{tabular}




\begin{tabular}{|c|c|c|c|c|c|c|}
\hline \multirow{2}{*}{ Observed variables } & \multicolumn{6}{|c|}{ Factor loadings } \\
\hline & 1 & 2 & 3 & 4 & 5 & 6 \\
\hline REWARD $_{5}$ & & & & & .643 & \\
\hline REWARD $_{1}$ & & & & & .603 & \\
\hline EMPOWER $_{3}$ & & & & & & .753 \\
\hline EMPOWER $_{2}$ & & & & & & .742 \\
\hline EMPOWER $_{1}$ & & & & & & .709 \\
\hline EMPOWER $_{4}$ & & & & & & .680 \\
\hline Eigenvalue & 5.827 & 3.931 & 2.576 & 1.907 & 1.748 & 1.441 \\
\hline Average Variance Extracted (\%) & 23.309 & 15.723 & 10.306 & 7.626 & 6.992 & 5.763 \\
\hline Accumulative Average Variance Extracted (\%) & 23.309 & 39.032 & 49.338 & 56.964 & 63.956 & 69.719 \\
\hline
\end{tabular}

Source: Analysis result

The results of the EFA analysis, using the principal component method and the Varimax, extracted 6 factors from 25 observed variables and accumulative average variance extracted was $69.719 \%$ (satisfactory $>50 \%$ ) (Table 5).

Table 6. Results of the EFA of staff commitment scale.

\begin{tabular}{ll}
\hline Observed variables & Factor loadings \\
\hline COMMIT $_{5}$ & .847 \\
COMMIT $_{2}$ & .836 \\
COMMIT $_{1}$ & .790 \\
COMMIT $_{3}$ & .755 \\
COMMIT $_{4}$ & .691 \\
Eigenvalue & 3.086 \\
Average Variance Extracted (\%) & 61.730 \\
Accumulative Average Variance Extracted (\%) & 61.730 \\
\hline
\end{tabular}

Source: Analysis result
Factor analysis of staff commitment, Barlett's test with sig $=0.000, \mathrm{KMO}=0.748$ (between 0.5 and 1 ), the variables close to each other in the whole are correlated and EFA is appropriate (Table 6).

EFA with the principal component extraction method and Varimax extracts a factor with 5 observed variables and accumulative average variance extracted of $61.730 \%$ (> 50\%), which is satisfactory.

\subsection{Correlation Analysis}

The correlation matrix in Table 7 shows the Pearson (r) correlation coefficients between study variables and the significance level of each factor. The significance level of the coefficients is very small $(\mathrm{sig}=0<0.05)$ so the correlation coefficients are statistically significant.

Table 7. Correlation between organization culture factors and the staff commitment.

\begin{tabular}{|c|c|c|c|c|c|c|c|c|}
\hline & & COMMUN & TRAIN & INNOV & TEAM & REWARD & EMPOWER & COMMIT \\
\hline \multirow{2}{*}{ COMMUN } & Pearson & 1 & $.401 * *$ & -.133 & $.151 *$ & -.016 & $.280 * *$ & $.189^{* *}$ \\
\hline & Sig. (2-tailed) & & .000 & .060 & .033 & .820 & .000 & .004 \\
\hline \multirow{2}{*}{ TRAIN } & Pearson & $.401 * *$ & 1 & -.022 & $.310 * *$ & $.252 * *$ & $.193 * *$ & $.355 * *$ \\
\hline & Sig. (2-tailed) & .000 & & .761 & .000 & .000 & .006 & .000 \\
\hline \multirow{2}{*}{ INNOV } & Pearson & -.133 & -.022 & 1 & $.226^{* *}$ & $.160 *$ & $.257 * *$ & $.458 * *$ \\
\hline & Sig. (2-tailed) & .060 & .761 & & .001 & .024 & .000 & .000 \\
\hline TEAM & Pearson & $.151 *$ & $.310 * *$ & $.226 * *$ & 1 & $.307 * *$ & $.291 * *$ & $.482 * *$ \\
\hline \multirow{2}{*}{ REWARD } & Pearson n & -.016 & $.252 * *$ & $.160 *$ & $.307 * *$ & 1 & $.170 *$ & $.343 * *$ \\
\hline & Sig. (2-tailed) & .820 & .000 & .024 & .000 & & .016 & .000 \\
\hline \multirow{2}{*}{ EMPOWER } & Pearson & $.280 * *$ & $.193 * *$ & $.257 * *$ & $.291 * *$ & $.170 *$ & 1 & $.207 * *$ \\
\hline & Sig. (2-tailed) & .000 & .006 & .000 & .000 & .016 & & .003 \\
\hline \multirow{2}{*}{ COMMIT } & Pearson & $.189 * *$ & $.355^{* *}$ & $.458 * *$ & $.482 * *$ & $.343 * *$ & $.207 * *$ & 1 \\
\hline & Sig. (2-tailed) & .007 & .000 & .000 & .000 & .000 & .003 & \\
\hline
\end{tabular}

**. Correlation is significant at the 0.01 level (2-tailed).

*. Correlation is significant at the 0.05 level (2-tailed).

Source: Analysis result

\subsection{Linear Regression Analysis}

The author uses the linear regression with the Enter method.

Table 8. Level of explanation of the model.

\begin{tabular}{|c|c|c|c|c|c|}
\hline Model & $\mathbf{R}$ & $\mathbf{R}^{2}$ & Adjusted $\mathbf{R}^{2}$ & Error estimates & Durbin-Watson's Coefficient \\
\hline 1 & $0.678^{\mathrm{a}}$ & 0.460 & 0.443 & 0.39271 & 1.788 \\
\hline
\end{tabular}

a. Independent variables: (Constant), EMPOWER, REWARD, INNOV, TRAIN, TEAM, COMMUN

b. Dependent variables: COMMIT

Source: Analysis result 
Table 8 shows that adjusted $\mathrm{R}^{2}$ is 0.443 , meaning $44.3 \%$ of the COMMIT variance (Employee Engagement) is explained by the variability of the 6 independent variables EMPOWER, REWARD, INNOV, TRAIN, TEAM, COMMUN. In addition, the Durbin-Watson test $\mathrm{d}=1.788(1<\mathrm{d}<3)$, with no correlation between residuals.

Table 9. Relevance of the model: Analysis of ANOVA.

\begin{tabular}{lllllll}
\hline Model & & Total square & Degree of freedom (df) & Average square & F & Sig. \\
\hline \multirow{4}{*}{1} & Regression & 25.217 & 6 & 4.203 & 27.253 & $0.000^{\mathrm{b}}$ \\
& Residuals & 29.610 & 192 & 0.154 & & \\
& Total & 54.827 & 198 & & & \\
\hline
\end{tabular}

a. Dependent variables: COMMIT

b. Independent variables: (Constant) EMPOWER, REWARD, INNOV, TRAIN, TEAM, COMMUN

Source: Analysis result

In the variance analysis table (Table 9), the F value has Sig. $=0.000(<0.05)$, the linear regression model presented is consistent with the data collected and the variables are statistically significant at the $5 \%$ level.

Table 10. Statistical analysis of regression coefficients.

\begin{tabular}{|c|c|c|c|c|c|c|c|c|}
\hline \multirow{2}{*}{\multicolumn{2}{|c|}{ Model }} & \multicolumn{2}{|c|}{ Unstandardized coefficient } & \multirow{2}{*}{$\begin{array}{l}\text { Standardized coefficient } \\
\text { Beta }\end{array}$} & \multirow{2}{*}{$\mathbf{t}$} & \multirow{2}{*}{ Sig. } & \multicolumn{2}{|c|}{ Multi-collinearity } \\
\hline & & B & Standard error & & & & Tolerance & VIF \\
\hline \multirow{7}{*}{1} & (Constant) & .238 & .274 & & .869 & .386 & & \\
\hline & COMMUN & .111 & .045 & .152 & 2.479 & .014 & .745 & 1.343 \\
\hline & TRAIN & .196 & .063 & .192 & 3.111 & .002 & .737 & 1.356 \\
\hline & INNOV & .353 & .049 & .416 & 7.236 & .000 & .851 & 1.174 \\
\hline & TEAM & .334 & .071 & .283 & 4.716 & .000 & .782 & 1.279 \\
\hline & REWARD & .128 & .047 & .159 & 2.756 & .006 & .846 & 1.183 \\
\hline & EMPOWER & -.082 & .055 & -.089 & -1.494 & .137 & .793 & 1.261 \\
\hline
\end{tabular}

a. Dependent variables: COMMIT

Source: Analysis result

The Variance Inflation Factor (VIF) maximum value of 1.356 (less than 10) indicates that the independent variables do not have multi-collinearity (Table 10).

The standardized residual frequency histogram shows that the standard variance of the residuals is approximately Normal $=1.09 \mathrm{E}-14$ (near zero) and standard variance $=0.985$ (approximately 1). The hypotheis of standard distribution of the residuals is not wrong. The P-P frequency map shows the points of the residuals disperse randomly around the diagonal (expected line), assuming the normal distribution of residuals is satisfied. Distributed graphs have a uniform distribution, assuming constant variance of the regression model is not violated. The above results show that the assumptions of the linear regression function are not violated and the regression model constructed is consistent with the whole. The standardized regression equation has the form:

$\mathrm{Y}=0.238+0.111 \mathrm{X}_{1}+0.334 \mathrm{X}_{2}+0.196 \mathrm{X}_{3}+0.128 \mathrm{X}_{4}+0.353 \mathrm{X}_{5}$

$\mathrm{X}_{1}$ : Organization Communication (COMMUN);

$\mathrm{X}_{2}$ : Teamwork (TEAM);

$\mathrm{X}_{3}$ : Training and Development (TRAIN);

$\mathrm{X}_{4}$ : Reward and Record (REWARD);

$\mathrm{X}_{5}$ : Innovativeness (INNOV);

Y: Staff commitment (COMMIT).

From the above analysis, the model is consistent with the research data and there are five accepted hypotheses.

\section{Conclusion and Managerial Suggestions}

\subsection{Conclusion}

The results show that the organization culture factors influence the staff commitment. Employees are currently attached to the company at an average level (average value = 3.4623). The whole scale used in the study is reliable (Cronbach's Alpha $>0.7)$. The study indicates that there are 5 elements of organization culture that correlate with staff commitment, arranged by decreasing importance: Innovativeness $\left(\beta_{3}=0.416\right)$, Teamwork $\left(\beta_{4}=0.283\right)$, Training and Development $\left(\beta_{2}=0.192\right)$, Reward and Record $\left(\beta_{5}=0.159\right)$ and Organization Communication $\left(\beta_{1}=0.152\right)$.

\subsection{Managerial Suggestions}

\subsubsection{Innovativeness}

Research results show that "Innovativeness" is the most influential factor in the staff commitment in the group of 5 cultural factors in the study area of the research. This is in line with the practice in the company specializing in information technology (IT), telecommunications (VT). In CMC Telecom, much of the work require effort to learn new knowledge and propose new ideas to solve problems that help improve work efficiency, so the innovative element in the job plays an important role in creating a breakthrough in 
work. Therefore, this is one of the peculiarities of organization culture to keep the people who are capable, always want the work done creatively.

The company should focus on encouraging staff innovation, creativity. Of course, when applying a new way of working or a new idea to the job, some of the risks will appear to make the project undue, so companies need to consider encouraging innovation at the time and in the group. Proper work is needed to ensure the progress of work as well as improve the efficiency of work through new ideas. In CMC Telecom, a large part of the work is carried out in a process with specific work steps, leading to staff feeling bound by the process, which explains the results of this study Therefore, to enhance creativity in the work, the company does not just stop at the incentive to encourage employees to develop new ideas, but also to improve the process of creating the environment for employees to reach out to suggest innovative ideas. In practice, some ICT companies have encouraged staff to attend international technology conferences (ASICON, ASSCC, ICDV, etc.) to present their research and learn more. experience, thereby stimulating the creation of new ideas in the workplace and the contribution of employees is expressed beyond the reach of the company. These activities should be further encouraged to improve work efficiency and increase the commitment of qualified staff.

\subsubsection{Teamwork}

The results show that "Teamwork" is the second most important factor. In CMC Telecom, teamwork is always promoted by the nature of work that requires effective collaboration of all members, Effective teamwork will bring success to projects while also bringing the excitement of the staff to the job they are assigned. Especially in the field of IT - telecom, most of the employees under the age of 30 with skills are not high compared with foreign IT companies such as Japan, US... Technical level of a person may not fully meet the requirements of the job, teamwork will help each individual to have confidence in his or her work and improve their skills, thereby affecting the staff commitment. The level of specialization, division of labor is higher, especially in large corporations, companies with high complexity, the cooperation, team spirit and support each other have become an urgent need. It requires all of the same respect, effort, contribution and chain of work together to accomplish the goal of the group. Especially, the IT industry has a working environment which requires the support of all members of the group as well as outside the group, the culture of the group needs to be promoted. Team spirit also helps to create a harmonious atmosphere, fun, cooperation, relieving stress, pressure and that is a unique element of the industry environment.

CMC Telecom needs to focus on improving the efficiency of teamwork by teaming its staff not only within the same department but also by expanding the collaboration between departments in the company. An atmosphere of harmonious work, cooperation, mutual respect, willingness to share experiences and support each other when necessary in the group of staff will create a cultural link for groups, departments, a comfortable and bright working environment, and increase the commitment of employees. Increased internal communication can be accomplished through the rearrangement of reasonable office space. The company should focus on team building activities, team building inside and outside the company, exchanges between departments, team activities, sports, arts to increase communication, to help internal and external staff understand the work, the difficulties of each other to cooperate and develop. Team building is not just between employees but also between employees and superiors. This relationship greatly influences the performance of the organization's common goals. In order to create a close, harmonious team, managers need to limit the power barriers, the process of smooth communication and the staff with the information they need to do the job. Managers must always support and motivate employees to accomplish their tasks. In addition, in order to enhance the spirit of teamwork, towards the common goal of the group, the department, the organization, the company should implement the staff evaluation policy associating individual results with collective results. However, the rate of individual and collective outcomes should be considered appropriate for each specific group in order to best promote personal and collective capacity, to avoid dependence, or dissatisfaction due to the noncooperation of some individuals that affect the outcome of the group.

\subsubsection{Training and Development}

The results show that "Training and Development" is ranked No. 3. Good training and development make the level of staff commitment higher. Training makes them more confident, more knowledgeable to fulfill their assigned tasks, to learn; challenging working environment will help them constantly improve themselves and they will work hard to apply their skills to work. They will also stick with the company from one development to another. Research results are quite reasonable in CMC Telecom, because of the high level of staff (over $82.4 \%$ of colleges, universities and postgraduate) and young people always aspire to capacity development. A number of ICT companies have developed training and development policies to improve their professional skills. Some activities, such as setting up courses from elementary to advanced level, 10 years of teaching experience, teaching staff are senior experts from countries with high scientific level such as Japan, United States... In addition, short courses of soft skills (art communication skills, problem-solving skills, etc.) with professional teaching staff are regularly organized by the company to improve the skills of employees, good service for work.

Solutions to improve the efficiency of training staff development should be focused by the company. In addition to implementing employee skill enhancement courses, companies should consider evaluating the effectiveness of their courses on current employee performance through an annual survey of all employees. Accordingly, the company 
considers adjusting the training content to be appropriate to avoid waste of training costs, wasting time participating in the courses of staff. In addition, due to the nature of the IT telecom industry, employees need to constantly improve their skills in using new tools and software for their work, so the company should partner with other organizations to organize workshops to train the skills of employees. Of course, these seminars will cost the company, but at an appropriate level will assist staff to improve their skills in using effective tools and software. In addition, the ICT industry in Vietnam is young (less than 15 years of operation) when compared with foreign companies such as Japan and the United States... The consideration to send employees abroad to improve their skills is essential in the long-term development strategy of the company, which will shorten the gap in capacity of IT staff in the country than foreign companies, creating a competitive advantage. for businesses in the international work environment, confirming IT-telecom employees are considered the property of the company.

\subsubsection{Reward and Record}

The results show that the "Reward and Record" factor is ranked No. 4. Due to their professional nature, IT jobs require employees to be under constant pressure, such as designing software, hardware, etc, the creativity, updating of new knowledge of technology in a continuous way. Therefore, the compensation paid to an employee for his or her work must be commensurate with the capacity, effort and try that they have spent to complete the work assigned. Salaries help employees pay for all personal and family expenses and assert their own capacity. Therefore, they are willing to go to another workplace for a more attractive income. In order to retain talents, to enhance the sticking of employees in the IT field, managers need to make reasonable and attractive income levels with their capabilities.

The compensation should be based on the work performed by an employee to reflect the individual's ability, the fairness of the job and the complexity of the job as well as the titles and positions such as Project Manager, Team Leader, Consultant, Software engineer, Hardware engineer, Employee Tester... Each job is clearly described, each employee is monitored and evaluated comprehensively throughout the work. There are prizes for employees when they finish their job in the best way. Managers need to clearly and concretely define the achieved salary conditions, the level of rewards, and most importantly, always create the most favorable conditions and opportunities for all employees to strive for.

It is not always giving employees tangible rewards, records can be made with compliments, positive feedback from the manager, awarding a certificate of merit and notifying to all employees. Praise, recognition when staff perform their work well will encourage their work spirit, they can feel the boss's recognition of what they have done and will continue to be more involved in the work for the development of the company. On the other hand, the manager needs to use the compliment effectively, timely, to the right degree and the right reason to stimulate the work spirit and to appreciate the importance of what he is doing. In addition, in the results achieved by the individual, the leader should raise the level of cooperation and support of the team to create motivation for other members.

For employees with long-standing experience, good work etiquette, there should be fair remuneration, and prioritizing opportunities for promotion in the workplace.

\subsubsection{Organization Communication}

Results show that "Organization communication" is the last of the five organization culture factors that influence staff commitment. In CMC Telecom, the work requires employees to continuously exchange their cooperation with domestic and foreign colleagues, customers and partners providing software solutions. Therefore, this is also a cultural feature to retain employees.

The company should promote the exchange of information that helps each other, between departments, to facilitate the completion of the work of the organization. In addition, twoway communication between the supervisor and the subordinate is equally important. By having complete and accurate information, they have the basis to solve difficulties and problems in the work in a timely and rapid manner, reducing risks and costs incurred. In addition, it is necessary to build a harmonious atmosphere, cooperate with each other, share experiences, support each other and work together when necessary. If an employee does not receive work coordination, support, or respect and care from a manager or colleague, they are willing to leave their current job to find a better work environment.

Managers not only do their jobs but are also responsible for helping their subordinates to complete the project, providing technical support; since each IT employee will take on a part of the project, so they need to interact with each other throughout the work process, removing barriers, gaps between employees and supervisors during project implementation.

The company should regularly organize meetings sharing knowledge, experience, skills, techniques together because during the implementation of the project, each person is responsible for a part of the project, not the whole implementation. They do not understand all the issues so they need support from colleagues and managers. The company should receive comments from employees, and listen to their thoughts; if there is internal conflict or conflict among employees at all levels, managers need to provied timely resolution in this case.

Organizing collective birthday parties, trips, and picnicking for employees to create conditions for people to understand each other, stick together, and easy to understand, sharing with each other in work as well as in life will all contribute to stress reduction in work.

Managers in IT companies should, depending on the characteristics of specific departments, have time and corporate strategies that have policy plans to help their employees work well with employees of each departments, 
and other team members to complete the project in the best way.

\subsection{Research Limitations and Further Directions}

Although the research has been completed, there are some limitations as follows: Firstly, the study was conducted only with the research subjects in Ho Chi Minh City with convenient sampling method; secondly, research has not yet performed analysis of the differences between groups of employees such as software, hardware, computer networks, communication graphics..., thirdly, the study only researched emotional commitment, not paying attention to compulsive and standard commitment (Meyer and Allen, 1991). This is the clue for the next study.

\section{References}

[1] Angle, H. L., \& Perry J. (1981), "An empirical assessment of organizational commitment and organizational Effectiveness", Administrative Science Quarterly, 26, pp. 1-13.

[2] Bateman, T. S., \& Strasser, S. (1984), “A longitudinal analysis of the antecedents of organizationa commitment", Academy of Management Journal, 27, 1, pp. 95-112.

[3] Berg, P., Kallebert, A. L., \& Appelbaum, E. (2003), "Balancing work and family: The role of high-commitment Environments", Industrial Relations, 42, pp. 168-188.

[4] Boon, O. K., Safa, M. S., \& Arumugam, V. (2006), “TQM practices and affective commitment: a case of Malaysian semiconductor packaging organizations", International Journal of Management and Entrepreneurship, 2, 1, pp. 37-55.

[5] Delobbe, N., Haccoun, R., R., \& Vandenberghe, C. (2002), "Measuring core dimensions of organizational culture: A review of research and development of a new instrument", Universite catholique de Louvain, Belgium.

[6] Denison, D. R., \& Mishra, A. H. (1995), "Toward a Theory of Organizational Culture and Effectiveness", Organizational Science, 6, pp. 204-223.

[7] Harrison, R. (1992), Diagnosing Organizational Culture, San Francisco: Pfeiffer.

[8] Hellriegel, D., \& Slocum, J. W. (2001), Organisational Behavior. South-Western, pp. 523.

[9] Ilies, R., \& Judge, T. A. (2003), "On the Heritability of Job Satisfaction: The Mediating Role of Personality", Journal of Applied Psychology, 88, 4, pp. 750-759.

[10] Jaros, S. J., Jermier, J. M., Koehler, J. W., \& Sincich, T. (1993), "Effects of continuance, affective, and moral commitment on the withdrawal process: An evaluation of eight structural equation models", Academy of Management Journal, 36, pp. 951-995.

[11] Kanter, R. M. (1968), "Commitment and social organization: A study of commitment mechanisms in utopian Communities", American Sociological Review, 33, 4, pp. 499-517.

[12] Kalleberg, A. L., et al (1996), Organizations in America: Analyzing Their Structures and Human Resource Practice, Calif.: Sage Publications, Thousand Oaks, pp. 113-129.
[13] Khan, T. I., et at (2011), "Job Involvement as Predictor of Employee Commitment: Evidence from Pakistan", International Journal of Business and Management, 6, 4, pp. 252-262.

[14] Kroeber, A. L., Kluckhohn, C. (1953), Culture: a critical review of concepts and definitions, Papers of Peabody Museum, Harvard University, 47 (1), pp. 158.

[15] Lau, H. C., \& Iris, M. A. (2001), "The soft foundation of the critical success factors on TQM implementation in Malaysia, The TQM Magazine, 13, 1, pp. 51-62.

[16] Luthan, F. (1995), Organisational Behaviour, McGraw Hill, NewYork.

[17] Manetje, O. M., \& Martins, N. (2009), "The relationship between organisational culture and organisational Commitment", Southern African Business Review, 13, 1, pp. 87-111.

[18] Martins, E., Martins, N. (2002), “An organizational culture model to promote creativity and innovation", SA Journal of Industrial Psychology, 28, 4, pp. 58-65.

[19] Mayer, R. C., \& Schoorman, F. D. (1992), "Predicting participation and production outcomes through a twodimensional model of organisational commitment", Academy of Management Joumal, 35, 3, pp. 671-684.

[20] Mejia, L. G., et at (2002), Management: People, Performance, Change, Mcgraw-Hill, p. 108.

[21] Meyer J., \& Allen N. (1997), Commitment in the Workplace: Theory, Research, and Application, Sage Publications, Thousand Oaks, pp. 150.

[22] Meyer, J. P., \& Allen, N. J. (1991), "A Tree-component conceptualitazation of organizational commitment", Human Resource Management Review, 1, pp. 61-89.

[23] Mowday, R. T., Steers, R. M., \& Porter, L. W. (1979), "The measurement of organizational commitment", Journal of Vocational Behavior, 14, pp. 224-247.

[24] Northcraft, G. B., \& Neale, M. A. (1996), Organisation Behaviour, Prentice-Hall, London.

[25] O'Reilly, C., \& Chatman, J. (1986), “Organizational Commitment and Psychological Attachment: The Effects of Compliance, Identification and Internalization on Prosocial Behavior", Journal of Applied Psychology, 71, 3, pp. 492-499.

[26] O'Reilly, C. A., et al (1991), "People and organizational culture: A profile comparison approach to assessing personorganization fit", Academy of Management Journal, 34, pp. 487-516.

[27] Pettegrew, A. M. (1979), "On Studying Organizational Cultures”, Administrative Science Quarterly, 4, pp. 570-581.

[28] Penley, L. E, \& Gould, S. (1988), "Etzioni's model of organizational involvement: A perspective for understanding commitment to organizations", Journal of Organizational Behavior, 9, pp. 43-59.

[29] Porter, L. W., Steers, R. M., \& Boulian, P. V. (1974), "Organizational commitment, job satisfaction, and turnover among psychiatric technicians", Journal of Applied Psychology, 59, pp. 603-609.

[30] Ricardo, R., \& Jolly, J. (1997), "Organizational culture and teams”, S. A. M. Advanced Management Journal, 62, 2, p. 4-7. 
[31] Sarros, J. C., Gray, J. H. \& Densten, I. L. (2003), The next generation of the organizational culture profile, Monash University.

[32] Schein, E. H. (2004), Organizational Culture and Leadership, Jossey-Bass, San Francisco.

[33] Steers, R. M. (1977), "Antecedents and outcomes of organizational commitment", Administrative Science Quarterly, 22, pp. 46-56.

[34] Wallach, E. J. (1983), "Individuals and organizations. The cultural match", Training and Development Journal, 37, 2, p 29-36.

[35] Yuen et al (2014), "Organizational commitment of white collar employees in damansara heights, Kuala Lumpur", Journal of Social Economics Research, 1, 7, pp. 156-168.

\section{Biography}

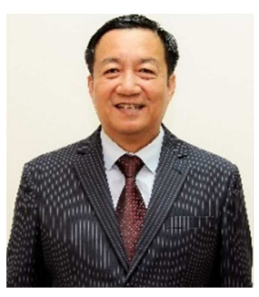

Ha Nam Khanh Giao, Assoc.Prof.PhD Ha Nam Khanh Giao is Dean of the Faculty of Air Transport Facilities, Vietnam Aviation Academy, Vietnam nowadays. He used to be Director of The Institute of Applied Economics, Head of the Faculty of Post Graduates Study, Dean of the Faculty of Tourism and Hospitality, University of Finance and Marketing, Vietnam. He supervised successfully 4 doctors and more than 200 masters. He is reviewer of 12 journals, and published more than 150 articles in the scientific journals. His research fiels are marketing, international business, services management, human resources management, tourism and hospitality. 